\title{
Experimental Investigation of Green Roof Impact on Buildings Energy in Hot Climate
}

\author{
Farah Abdul Kadhum Malik ${ }^{a}$, Alaa Liaq Hashem ${ }^{a *}$ \\ ${ }^{a}$ Department of mechanical engineering, University of Al-Qadisiyah, Al-Qadisiyah, Iraq.
}

\section{ART ICLE INFO}

\section{Article history:}

Received 06 May 2020

Received in revised form 22 June 2020

Accepted 25 June 2020

\section{Keywords:}

Green roofs

Eco-roofs

Building energy

\begin{abstract}
A B S T R A C T
Green roofs are a layer that effectively working on blocks of solar radiation from entering the building's structure below partially. Its work as a passive cooling technique, and have the potential to reduce the high surface temperature of conventional roofs because of the soil thermal resistance, evapotranspiration, and several effects for foliage shading. This affects the heat flux flow of the roof that in turn influences the indoor thermal conditions and the building energy demand. The research goals are to test the influence of the green roof on reducing heat transfer to the interior of heavy structural buildings. The experimental part was done to examine the effect of the green roof and compare it with a standard roof under influence of ambient air temperature, solar radiation, and wind speed and test the effect of the green roof on reducing heat transfer inside the building. The model site was at the Diwanyah city (Latitude: 31.9868 and Longitude: 44.9215), the engineering college campus, Qadisiyah University. The experimental setup includes two cubicles, with equal internal volume values $(163 \mathrm{~cm} * 163 \mathrm{~cm} * 105 \mathrm{~cm})$. The experimental results showed for the period 5-8 September 2019. The maximum zone temperature was $46.4{ }^{\circ} \mathrm{C}$ for traditional roof and $37.06{ }^{\circ} \mathrm{C}$ for the green roof at 3:24 p.m. The results showed that the maximum internal temperature was $46.97{ }^{\circ} \mathrm{C}$ and $36.42{ }^{\circ} \mathrm{C}$ for the traditional roof and green roof respectively at 3 p.m. Also, the results for period 18-21 July 2019 noted that the zone temperature decreased by $7.5^{\circ} \mathrm{C}$ and the maximum temperature of the internal traditional standard roof's surface is $45.66^{\circ} \mathrm{C}$ and $37.41{ }^{\circ} \mathrm{C}$ for the green roof.
\end{abstract}

(C) 2020 University of Al-Qadisiyah. All rights reserved.

\section{Introduction}

In Iraq, the buildings were constructed mainly from heavily weighted materials, with its presence in an environment in which summer is longer than winter and temperature differences between night and day are few, the overcooling problem exacerbates every year. This explains the high-energy consumption in this sector, which reached $38 \%$ of total energy production within the year 2018 [1]. Striking a balance between reducing energy consumption and provide a comfortable atmosphere and from other side restoring the environmental balance through the use of green roofs is an idea that was used in Iraq 6 thousand years ago in the hanging gardens of

Babylon. Green roofs are a passive cooling technique that minimizes incoming solar radiation from reaching the building structure below. Green roofs also referred as vegetated roofs [2], eco-roofs, roof gardens or living

* Corresponding author: Tel. + 9647807857061

E-mail address: alaa.almosawi@qu.edu.iq (Alaa L. Hashem) 


\begin{tabular}{|llll}
\hline \multicolumn{2}{l}{ Nomenclature } & \\
$A$ & Surface area in $\left(\mathrm{m}^{2}\right)$ & $U$ & Overall heat transfer coefficient in $\left(\mathrm{W} / \mathrm{m}^{2} \mathrm{~K}\right)$ \\
$k$ & thermal conductivity $\left(\mathrm{W} \mathrm{m}^{-1} \mathrm{~K}^{-1}\right)$ & Subscripts \\
$Q$ & Quantity of the heat trans $(\mathrm{W})$ & tr & traditional \\
$\boldsymbol{R}_{\boldsymbol{T}}$ & Total resistance & $\mathrm{Gr}$ & Green roof \\
$S$ & Body thickness $(\mathrm{m})$ & $\mathrm{C} . \mathrm{L}$ & Cooling Load \\
$T_{1}$ & Higher temperature $(\mathrm{K})$ & LR & Load Reduction \\
$T_{2}$ & Lower temperature $(\mathrm{K})$ & &
\end{tabular}

roofs [3, 4]. It is basically, a roof with plants in their final layer. Green roofs have a large impact on the inner roof temperature because of several effects: foliage shading, soil thermal resistance and evapotranspiration, etc. Therefore, the heat flux through the roof reduced, leads to influences on the building indoor thermal conditions and energy demand. The modern green roofs are designed and developed widely by Germany [5], where $10 \%$ of buildings use green roof construction technology [6]. Presently, countries such as Canada, the United States, Australia, Japan, and Singapore are also taking a serious initiative to use green roofs in modern buildings and modify old buildings. In the city of Toronto, Canada, the use of green roofing is imposed on the area between $20 \%$ and $60 \%$ of the overall roof area [7]. Similarly, in the city of Tokyo, Japan, the process of green roof design is accelerated by commissioning all new buildings to construct these roof designs. For instance, private buildings and having area higher than 1000 square meters and general buildings having an area higher than 250 square meters must be green to be equivalent to $20 \%$ of the roof or pay a fine of $\$$ 2,000 per year [6]. In the city of Portland, USA, all new buildings must be constructed with a green roof covering no less than $70 \%$ of the roof [8].

Due to the great importance and benefits offered by the green roofs, many previous studies and researches are showing their importance.

A detailed description of thermal performance, as well as runoff measurements of green surfaces in the city of Toronto, was provided by Liu and Minor [9]. Two extensive green surfaces were used with a lightweight growth medium and soil depth ranges $75-100 \mathrm{~mm}$. Although vegetation was minimal during the first year of the green roof, the flow of heat through the roof was reduced by $70-90 \%$ in the summer and $10-30 \%$ in the winter. Takebayashi and Moriyama [10] conducted their study in the state of Los Angeles in August 2004. A green roof (one with plants and one with bare soil surface that does not contain plants) and cement concrete surfaces were used. It was observed that the sensible heat fluxes on the green surface are little due to the huge latent heat fluxes through evaporation. Saiz, et al. [11] used life cycle assessment to estimate the advantages, particularly in terms of enhanced energy consumption, due to the use of a green roof to a multistory residential building located downtown in the city of Madrid, Spain. The findings indicated that environmental effects decreased more considerably in categories related to the generation of electricity and the use of a green roof is found to decrease energy consumption by around $1 \%$ per year. It might be noticed that such energy-saving is not large due to the fact that the green roof was used to only $16 \%$ of the buildings exposed surface area. Attia and Mahmoud [12] presented the green surfaces as a civilized landscape of healthy and productive cities, which are considered a solution to economic, environmental, and social problems in developing cities. The results showed that the most important benefits of agriculture in the roofs of houses is the economic burden of families, increasing the income of families. As a contribution to reduce pollution, contribute to low temperature, and reduce energy consumption, especially cooling capacity. environmental and social problems in developing cities. The first part of the study deals with a set of tools and design principles that contribute to transforming green surfaces into productive farms. While, the second part deals with successful cases in Cairo that includes residential units, gardens, and schools. The results showed that the most important benefits of agriculture in the roofs of houses is the economic burden of families, increasing the income of families. As a contribution to reduce pollution, contribute to low temperature, and reduce energy consumption, especially cooling capacity. Jaffal, et al. [13] provided an investigation of the effect of a green roof on the performance of building energy. A model consisted of a single-family house with a green roof was examined and implemented within a building code in order to evaluate soil surface temperatures and the green roof foliage. The authors found that the use of a green roof protects the roof slab from high-temperature fluctuations and extreme temperatures. Moreover, in the summer, a passive cooling effect was noticed with an increment in the daily heat losses through the roof by a factor of three using the green roof. It was concluded that the use of a green roof is an effective solution for the reduction of cooling demand and the improvement of thermal comfort. Moody and Sailor [14] studied the thermal performance of buildings through a model with a green roof. A new parameter was introduced called mechanical benefit of green roofs which is the ratio of energy use to heating, ventilation, and air conditioning of a traditional roof building to a green roof building. Based on field data from Portland, Oregon, the USA which used for validating their green roof model in the energy simulation program. The results showed that the advantages of a green roof depend strongly on the climate and location of the building. La Roche and Berardi [15] studied the potential of green roofs, in terms of energy saving, using the system different strategies, non-insulated, insulated, and variable insulated system. The system was located and examined in a dry and hot climate with moderate winters. The results showed that the variable green roof insulation was effective as it proved to change thermal capacity in the summer, this system and the system of a non-insulated green roof led to the lowest indoor temperature. The results indicated that the use of green roofs and isolated traditional roof systems in the winter season led to a preserve of high indoor temperature. Jim [16] explained the effect of building thermal insulation on cooling by green surfaces. The researcher assumed that buildings with poor thermal insulation are more useful in passive cooling in green roofs. A field experiment was conducted on the roofs of two buildings in the city of Hong Kong to evaluate electricity consumption for air conditioning in two cases of thermal insulation, one of which is good and the other poor. In addition, the study was included three types of roofing namely simple Sedum, herbaceous and Peanut, and three falls of snow for summer weather namely apricot, rainy and cloudy. In the event that the thermal insulation construction is not utilized, the cooling load is large throughout the day, and the installation of green roofs causes a significant decrease in the cooling load as well as saving energy consumption. Without building thermal insulation, green roofs will act as thermal insulation to restrict the internal heat entering the space. In addition, the water content within the green roof is important to enhance the conductivity and thermal capacity, and thus the heat transfer to the inner space. Coma, et al. [17] evaluated the thermal behavior of extensive green roofs by assessing thermal performance and energy consumption of three symmetric house-like rooms, with different roof structure system, located in the city of Puigverd de 
Lleida, Spain. One roof includes a traditional flat roof with an insulating layer, while an extensive green roof of $9 \mathrm{~cm}$ depth (pozzolana as drainage layer materials and comparing recycled rubber crumbs) was replaced the other two compartments. The results showed that both ceiling systems and extensive green roofs offer, $11.1 \%$ and $6.1 \%$, respectively, higher energy consumption than conventional roofing during heating periods The techniques that would reduce the thermal effect caused by the lack of green spaces in the city and the use of green roofs technology was studied by Saleem and Abdulrasoul [18]. The authors focused on how this reduces the thermal island and especially in hot climates. The finding showed that there is a relationship between increasing the area of green roofs and mitigation in heat where the experiment was conducted in the province of Najaf. It showed that the green roofs have the ability to reduce the thermal difference between the countryside and the city.

Jiang and Tang [19] analyzed the thermal and energy performance of the integration of night ventilation and a green roof. The thermal performance of the traditional and green roofs of three experiments on summer and sunny days was compared integrated on/off night ventilation mode. The results showed that a clear reduction in heat gains and the indoor air temperature was observed by integrating green roofs and night ventilation on a sunny day, while on a rainy day this reduction was not considerable. The reason behind this is that the cooling potential of night ventilation and a green roof extremely relies on the climate and thermal mass. The role of green space systems in achieving energy consumption related to buildings as well as carbon emissions was investigated by Besir and Cuce [20]. The authors assessed the multiple advantages of green roofs and facades such as shading, thermal insulation, and evaporation and the effect of evaporative cooling on green surfaces in reducing the demand for cooling in buildings. It was found that it is possible to reduce the solar heat gain into the buildings by about $80 \%$ from the green roof in the summer, that is, the green roof consumes energy of 2.2 to $16.7 \%$ of the traditional roofs in the summer. Also, a difference in temperature was found between the traditional roof and the green roof, by about $4{ }^{\circ} \mathrm{C}$, during the winter season.

\section{Problem Description}

The experimental set up consists of two cubicles, with identical internal volumes $(160 \times 160 \times 160 \mathrm{~cm})$ as shown in Fig. 1. Their foundations are concrete reinforced slabs of $(160 \times 160 \times 10 \mathrm{~cm})$. The compositions of the walls show the following layers from inside to outside: cement mortar, hard bricks $(24 \times 12 \times 8 \mathrm{~cm})$, and cement mortar as internal coating. The roof is the only construction surface that differs among the studied cubicles.

\subsection{Traditional Room}

The area identified for both models is buried with rough soil (subbase), after which the rough soil was compacted by steel wheel rollers to become one level and $10 \mathrm{~cm}$ high to be ready for construction. Laying the building floor consisting of concrete reinforced slabs $(1.60 \mathrm{~m} \times 1.60 \mathrm{~m} \times 0.10 \mathrm{~m})$ prefabricated for both models. The construction of the structure (walls) began directly above the previously precast floor, and the construction was carried out using two rows of hard bricks ( $24 \mathrm{~cm} \times 12 \mathrm{~cm} \times 8 \mathrm{~cm}$ ) and Iraqi cement. The walls $140 \mathrm{~cm}$ high for both models, while one side left open for laying the door as shown in Fig, 2.

Laying the base of the roof over the building structure for both models consisting of concrete reinforced slabs $(1.60 \mathrm{~m} \times 1.60 \mathrm{~m} \times 0.10 \mathrm{~m})$ prefabricated, and then the structure was built on the roof with a height of
$36 \mathrm{~cm}$ using hard bricks and cement. Then the walls were coated inside and outside with a layer of cement mortar 3:1 for both modules as shown in Fig. 3. A PVC door $(1.38 \mathrm{~m} \times 0.98 \mathrm{~m})$ was installed in the space designated for both models.

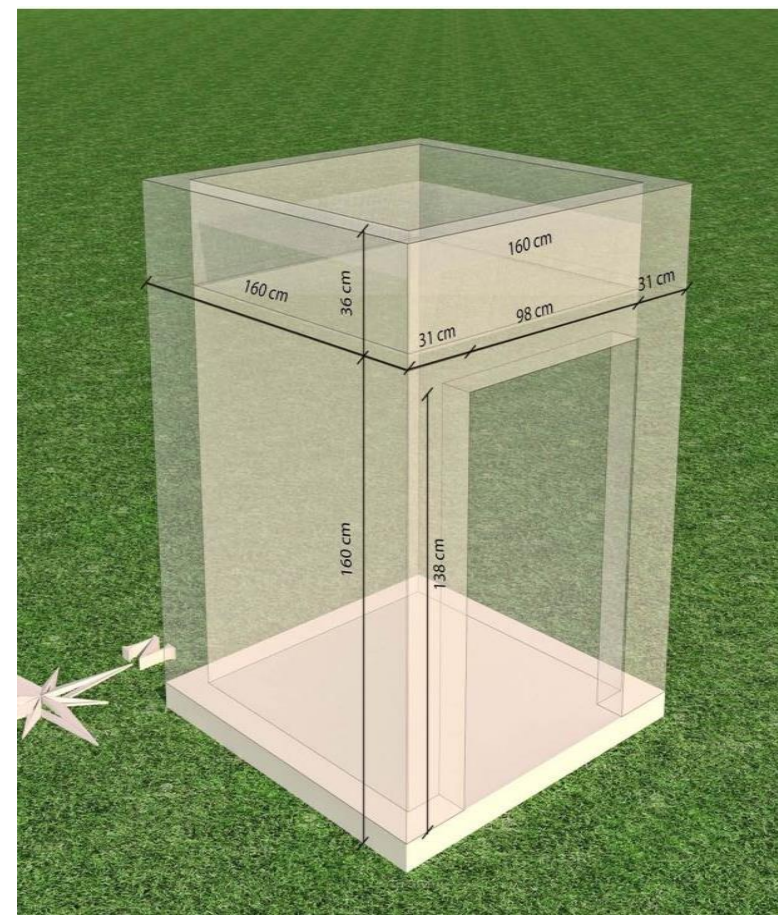

Figure 1. A 3-D graph of the experimental cubicle, dimensions in $\mathrm{cm}$.

The physical properties of the construction material listed in Table 1 $[21,22]$. The reference traditional insulated flat roof fabricated from multilayers as shown in Fig. 4, multi-layers covered the concert slap: layer of moisture resistance (asphalt) is located on reinforced concrete. A layer of $0.75 \mathrm{~cm}$ of polyethylene is placed above the asphalt layer, layer of river sand was placed with a thickness of $7 \mathrm{~cm}$, and the final surface is a layer of concrete tiles with a thickness of $3 \mathrm{~cm}$. The spaces between the tiles filled with mastic.

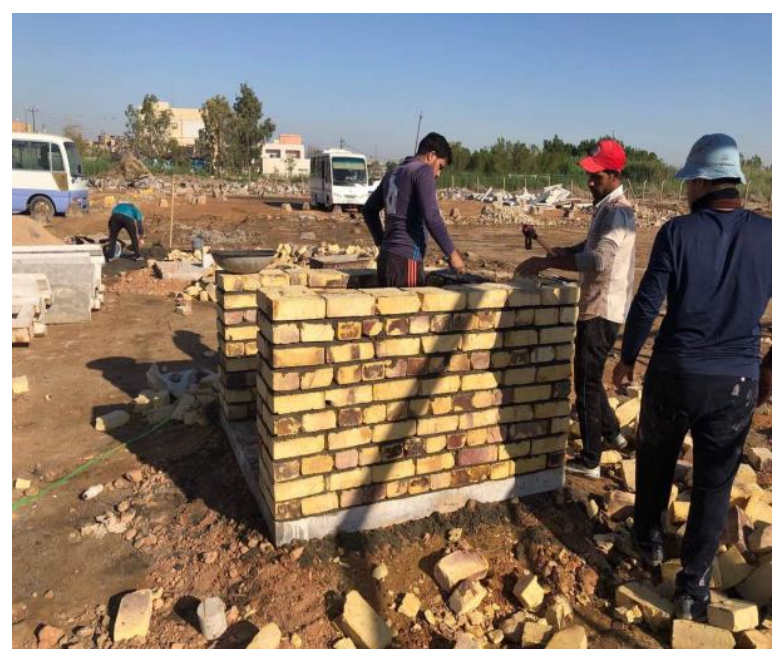

Figure 2. The construction process of the structure (walls). 


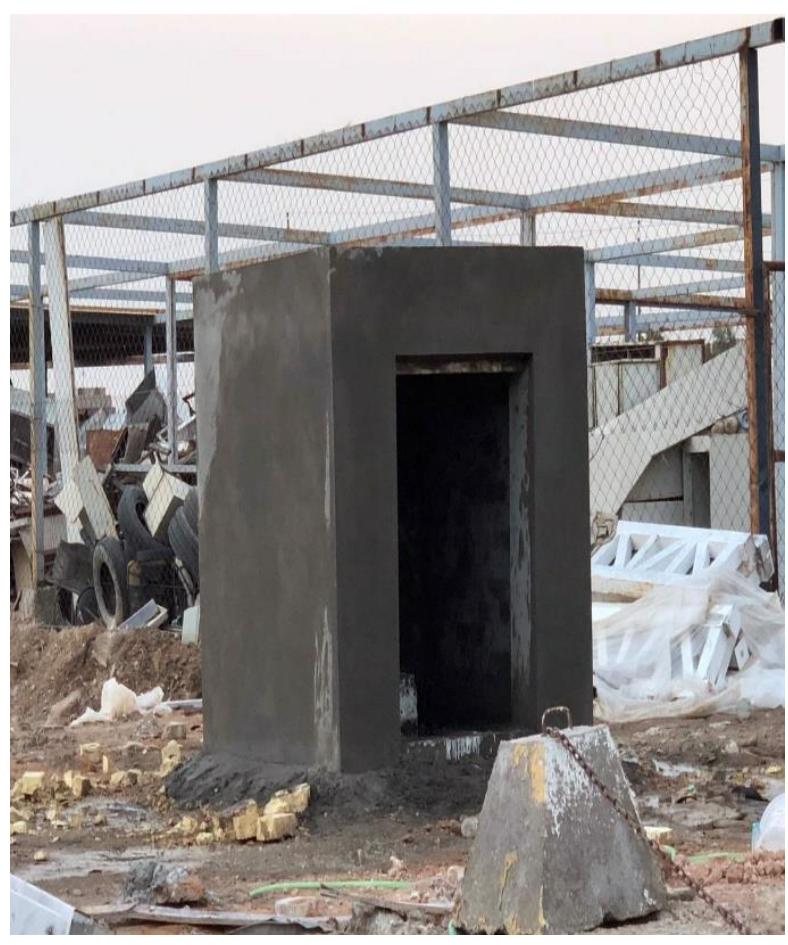

Figure 3. Covering the walls with cement mortar.

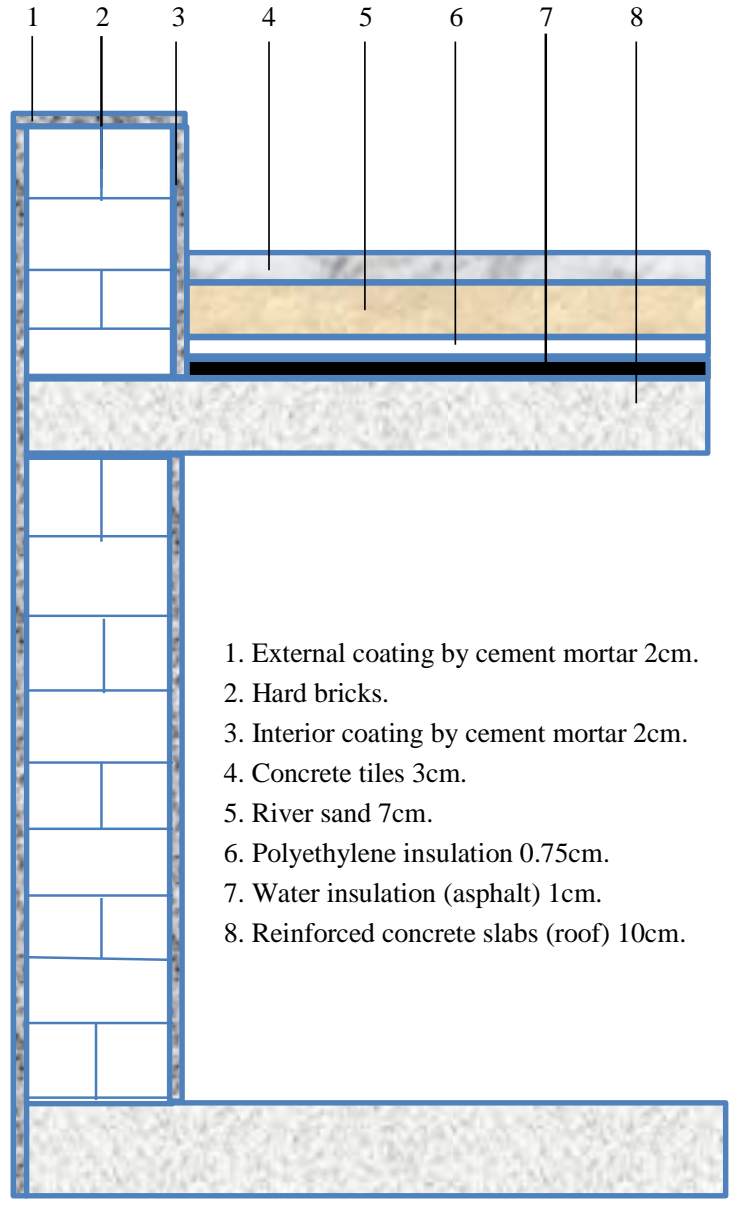

Figure 4. Construction section of the traditional Room.

Table 1. The physical properties of the construction mater. [21, 22]

\begin{tabular}{llllll}
\hline layers & $\begin{array}{l}\text { Thickness } \\
(\mathbf{m})\end{array}$ & Material & $\begin{array}{l}\text { Thermal conductivity } \\
(\mathbf{W} / \mathbf{m K})\end{array}$ & $\begin{array}{l}\text { Density } \\
(\mathbf{k g} / \mathbf{m} \mathbf{3})\end{array}$ & $\begin{array}{l}\text { Specific heat } \\
(\mathbf{J} / \mathbf{k g ~ K})\end{array}$ \\
\hline Internal and external Coating & 0.02 & Cement mortar 3:1 & 0.99 & 2020 & 2040 \\
bricks & 0.24 & Hard bricks & 0.54 & 1460 & 840 \\
Reinforced concrete 4:2:1 & 0.1 & Composed & 1.49 & 2300 & 840 \\
Concrete tiles & 0.03 & Sand, cement and gravel & 1.1 & 2100 & 837 \\
Water insulation & 0.01 & asphalt & 0.24 & 1070 & 1000 \\
Insulation & 0.0075 & Polyethylene & 0.037 & 30 & 1000 \\
River sand & 0.07 & Sand & 0.24 & 1690 & 1000 \\
Water proof protection & 0.07 & Gravel & 1.2 & 1700 & 920 \\
Relieved concrete & 0.02 & Light mortar & 0.41 & 900 & 1000 \\
\hline
\end{tabular}




\subsection{Green Room}

The experimental model structure is identical to the traditional model except for the layers added on the concert slab external surface which different and including the green layer. A layer of asphalt (water insulation) is laid on reinforced concrete. A layer of relieved concrete to obtain a slope of $2 \mathrm{~cm}$ thickness was placed over the asphalt layer. Then two polyethylene insulation layers of $1.5 \mathrm{~cm}$ thick laid on the relieved concrete, a single layer of gravel of $7 \mathrm{~cm}$ thickness as a drainage layer, substrate layer of $15 \mathrm{~cm}$ thickness, and the vegetation layer as shown in Fig. 5.

In addition, a water drainage system was done at the end of the roof from the bottom, in order to drain the excess water from the watering process. The drain hole was covered by a group of gravel on the drainage hole from the inside, in order not to drain the soil (growth medium). A type of grassland plant (Indian grass) was used as shown in Fig. 6, which adapts well to hot and dry climatic conditions during the summer period. Moreover, the drip irrigation system was used to preserve plants during the summer period.

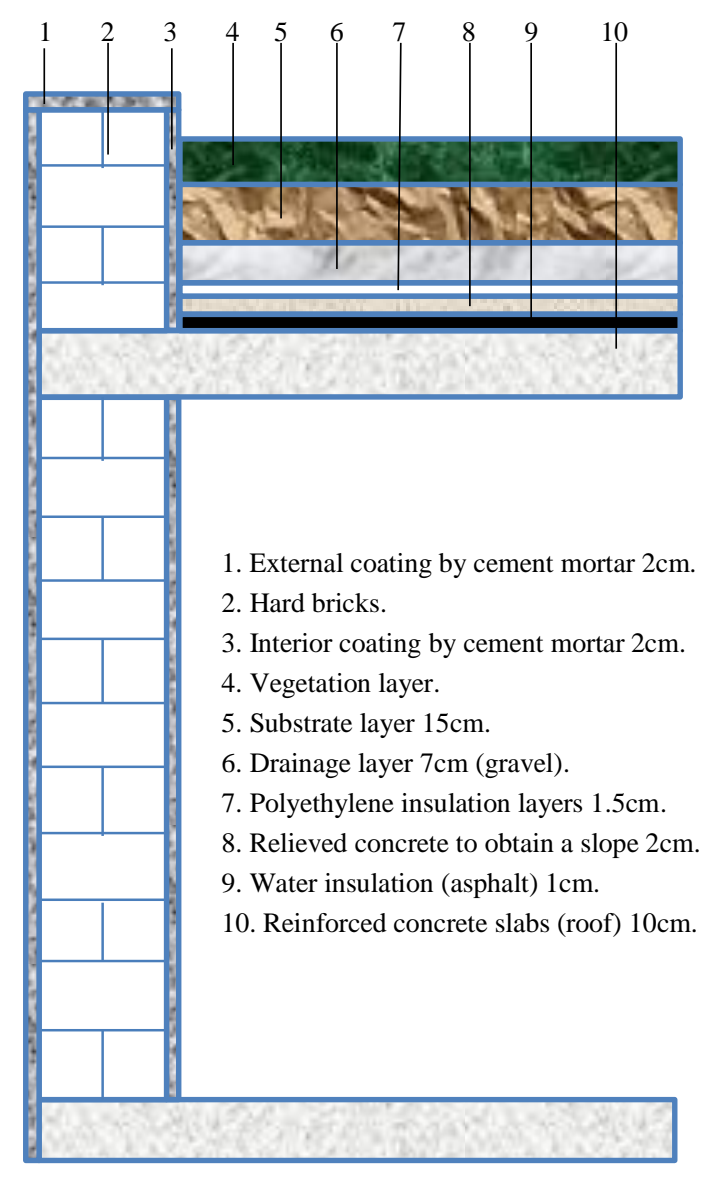

Figure 5. Construction section of the green roofs room.

The sensors were constructed for evaluating the thermal behavior of both models during experiments to measure the following: internal wall temperatures on the west and south, and the roof; internal and external ambient temperature; and external surface temperatures for the roof. An extra temperature sensor was placed at a height of $1 \mathrm{~cm}$ for both the traditional roof and the green roof at a height of $2 \mathrm{~cm}$ from the vegetation at the green roof.

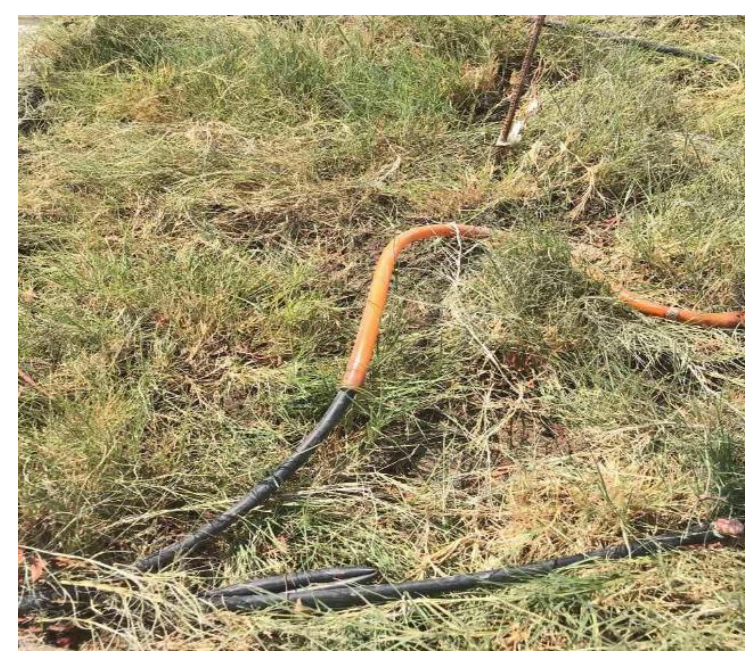

Figure 6. The growth of the grass plant on the surface of the green room.

\section{Mathematical Formulation}

\section{Heat transfer equation:}

The equation of heat transfer by conduction called Fourier Law can also be expressed as [23]:

$$
\begin{aligned}
Q & =U A\left(T_{1}-T_{2}\right) \\
Q & =\frac{1}{R_{T}} A\left(T_{1}-T_{2}\right) \\
R_{T} & =R_{\text {si }}+\sum R_{\text {lay }}+R_{\text {se }} \\
R & =\frac{K}{S}
\end{aligned}
$$

Where $\left(R_{s i}\right)$ represents Inner surface thermal resistance equal to $0.13,\left(R_{s e}\right)$ represents the external surface thermal resistance equal to 0.04 . [22]

\section{Load Reduction (\%):}

The reduction in load gain caused by using a green roof can be calculated as follow:

$$
L R=\frac{C . L_{\text {tr.room }}-C . L_{\text {gr.room }}}{\text { C.L } \text { tr.room }_{\text {trom }}}
$$

\section{Electricity cost savings:}

Electricity cost savings are calculated from the following formula [24]: Electricity cost saving $\left(\frac{\text { Dinar }}{\text { day }}\right)=$ cooling load reduction $(K W) *$

$$
30(\text { Dinar } / K W h) * 24(h / d a y)
$$




\section{Experimental work}

Experimental work was carried out to examine the effect of the green roof and compare it with a traditional roof under influence of ambient air temperature, wind speed, and solar radiation, and test the effect of a green roof on reducing heat transfer inside the building. The model site was at Adiwanyah city (Latitude: 31.9868 and Longitude: 44.9215), the Engineering College Campus, Qadisiyah University.

\section{Results and discussion}

The experimental results allow evaluating and comparing the thermal behavior and energy consumption, for the two construction systems during summer period. The weather in Diwaniyah is affected by the dry semitropical dry climate (desert), it is characterized by a hot dry climate in the summer. There is also a temperature fluctuation between day and night. The experiment was conducted in July and September of 2019. The experimental results include temperature measurements, wind speed, and solar radiation.

\section{1. for period 18-21 July 2019}

The boundary conditions for period 18-21 July 2019 include wind speed, ambient temperature, and solar radiation.

Figure 7. Shows the ambient temperatures of the air and solar radiation, which have a massive effect on green roofs' effectiveness. The higher the solar radiation is, the higher becomes the ambient air temperature. As for the Figure 8. Which shows the speed of the wind in this period. The higher the wind speed, the lower the temperature of the surrounding air, but significantly.

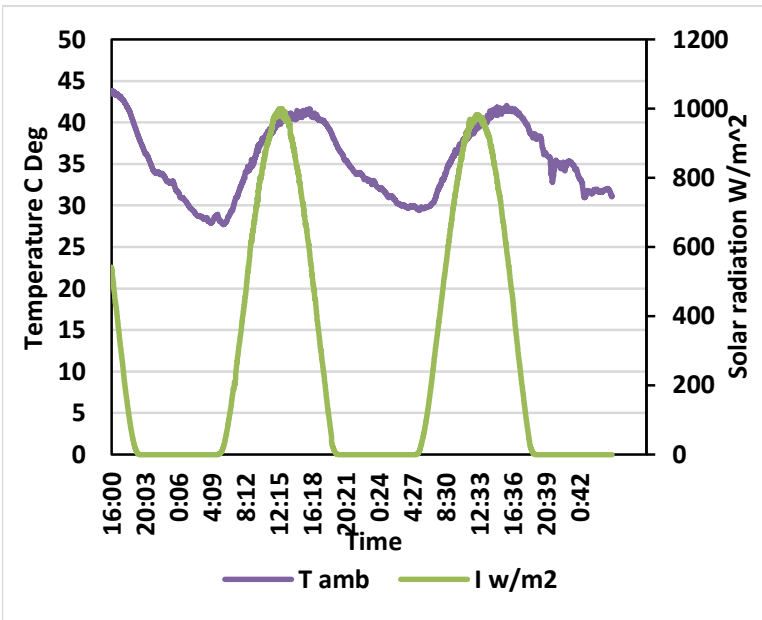

Figure 7. Ambient temperature and solar radiation.

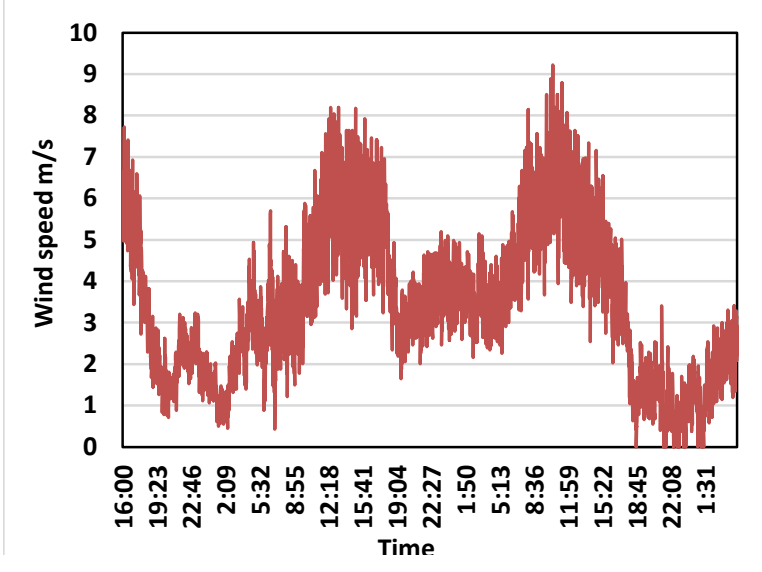

Figure 8. Wind speed.

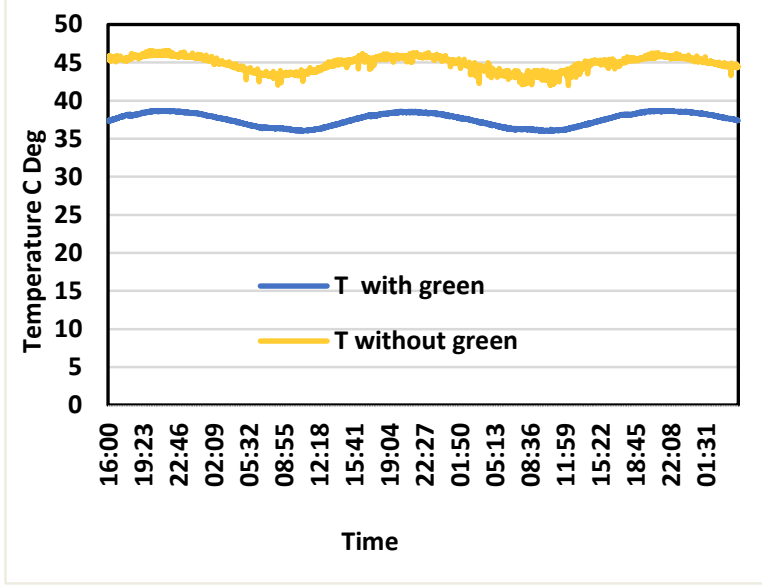

Figure 9. Zone temperature.

Fig. 9 Shows the temperature of the zone in the two rooms. The maximum temperature was $46.02{ }^{\circ} \mathrm{C}$ for traditional roof and $38.6{ }^{\circ} \mathrm{C}$ for the green roof,

We note that the zone temperature decreased by $7.42{ }^{\circ} \mathrm{C}$ in July. The decrease in temperature during the maximum solar radiation due to the effect of the green roof and the effect of the vegetation, which absorbs a large part of the solar radiation by shading. The process of evaporation that occurs in the growth substrate because it contains moisture, which decreases heat flow through the roof, thus reducing the temperature reaching that zone.

While Fig. 10 shows the temperature of the inner surface of the roof. Results showed that the maximum temperature was $45.66{ }^{\circ} \mathrm{C}$ and $37.41{ }^{\circ} \mathrm{C}$ for the traditional roof and green roof respectively. It can be noted that the green roof has significantly decreased the maximum inner surface temperature by $8.25{ }^{\circ} \mathrm{C}$. Again, the green roof reduces the heat flow inside the roof due to the presence of vegetation that absorbs/reflects a large part of the solar radiation incident on the surface due to shading and transpiration. In addition to the evaporative cooling process due to the presence of moisture in the soil, the substrate also acts as an insulating layer, which reduces heat flow and thus lowers the internal roof temperature. Therefore, a green roof has been used to reduce consumption of cooling energy during the summer and to request heating during the winter, as the green roof acts as an insulation layer. 


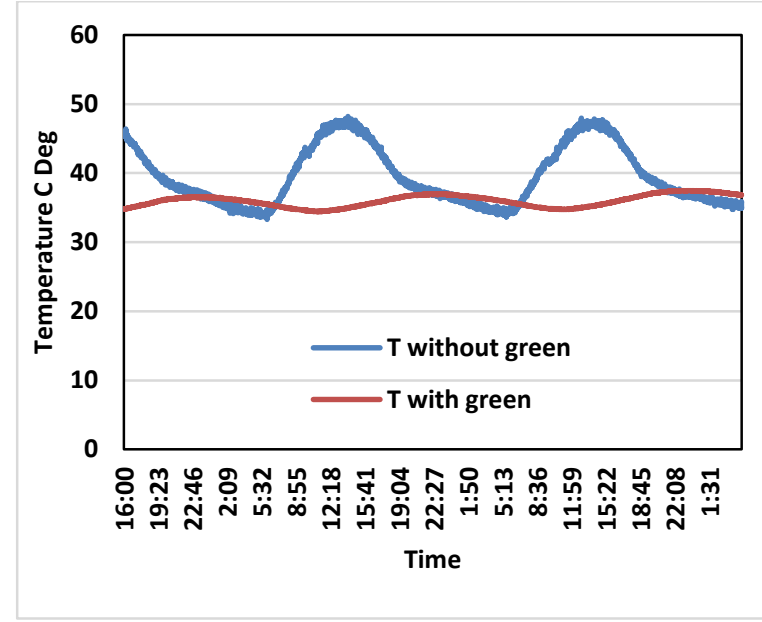

Figure 10. Roof internal surface temperature.

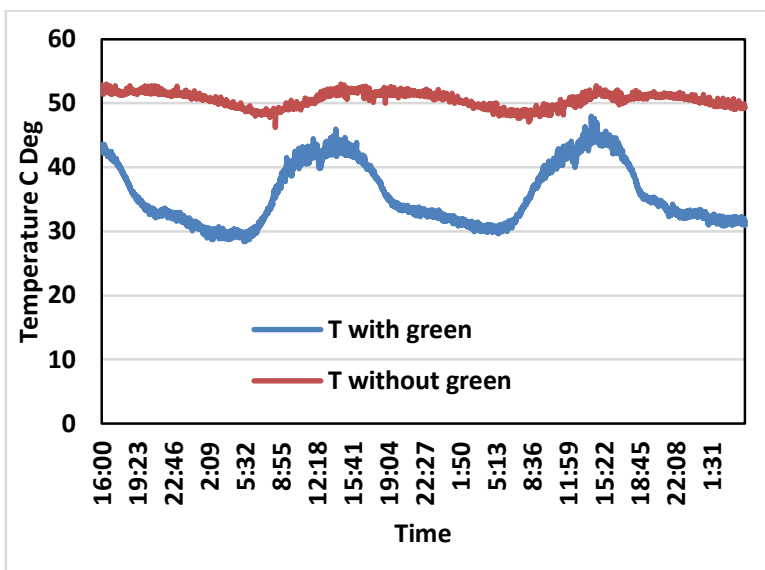

Figure 11. The temperature of the external surface of the roof.

In Fig. 11 the maximum temperature of the external surface of the roof decreased by a rate of $7.46{ }^{\circ} \mathrm{C}$, due to the presence of vegetation and the soil that acts as an insulating layer, thus reducing the heat flux of the roof.

\section{2. for period 5-8 September 2019}

The boundary conditions for period 5-8 September 2019 also include wind speed, ambient temperature, and solar radiation.

Fig. 12 shows that the ambient air temperature traces the solar radiation that occurred from sunrise to solar midday, after which a significant deviation in its behavior is indicated. It should be noted that the maximum ambient air temperature is around $43.18^{\circ} \mathrm{C}$ at 3:29 p.m., while the minimum ambient air temperature is $26.8^{\circ} \mathrm{C}$ at $6: 08$ a.m. The high ambient air temperature during the summer will affect green surfaces. Also, Fig. 12 shows the fluctuations in solar radiation value.

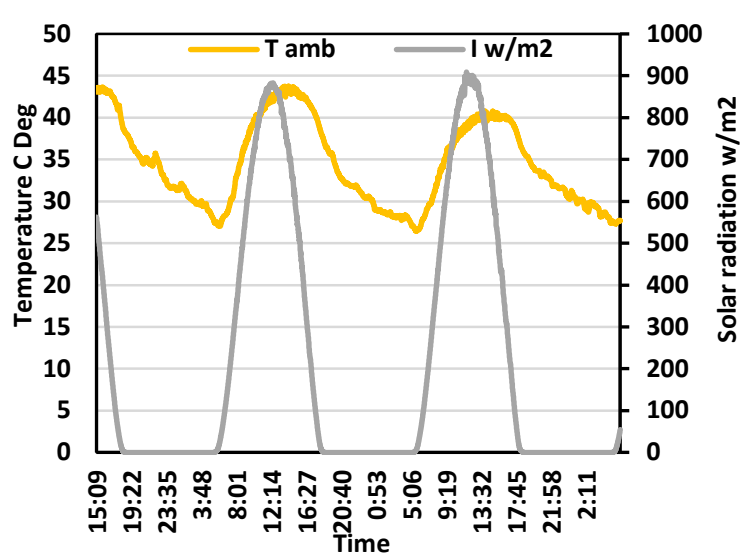

Figure 12. Ambient temperature and solar radiation.

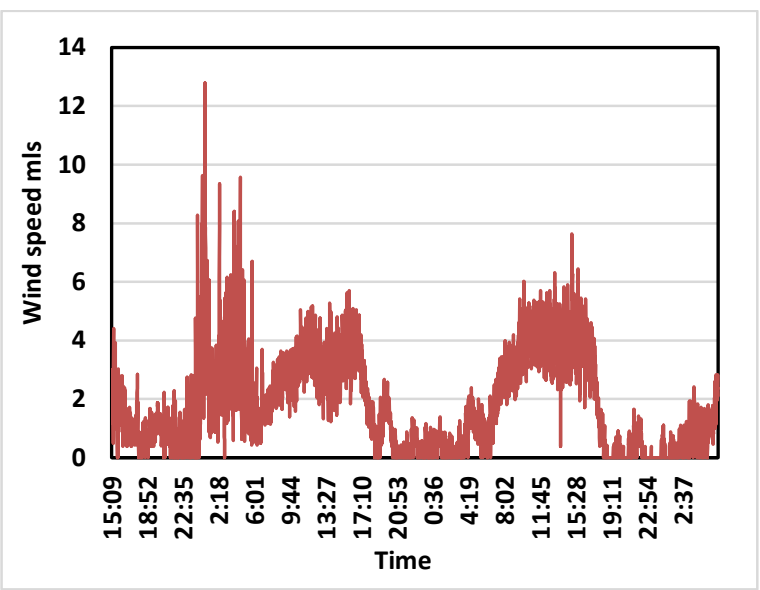

Figure 13. Wind speed.

The maximum solar radiation during the afternoon period is $876 \mathrm{~W} / \mathrm{m}^{\wedge} 2$ at $12: 44 \mathrm{pm}$, while the lowest solar radiation value reaches zero $\mathrm{W} / \mathrm{m}^{\wedge} 2$ during the absence of sunlight. And Fig. 13 shows that the wind speed has a limited effect on ambient temperature during the test period, where it decreases slightly with increasing wind speed. However, the trend of ambient air temperature continues to rise despite wind speed due to earth accumulating energy.

Fig. 14 shows the temperature of the zone in the two rooms. The maximum temperature was $46.4{ }^{\circ} \mathrm{C}$ for traditional roof and $37.06{ }^{\circ} \mathrm{C}$ for the green roof at 3:24 p.m. the zone temperature decreased by $9.34{ }^{\circ} \mathrm{C}$ in September, because the green roof reduces the heat flux entering the model by absorbing a large part of the solar radiation by shading and thermal insulation in addition to evaporative cooling. 


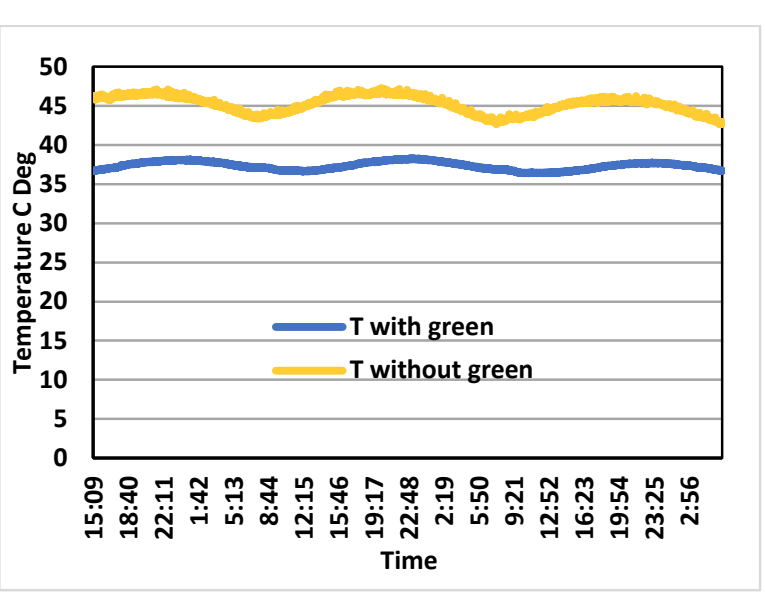

Figure 14. Zone temperature.

And Fig. 15 shows the temperature of the inner surface of the roof. Results showed that the maximum temperature was $46.97{ }^{\circ} \mathrm{C}$ and $36.42{ }^{\circ} \mathrm{C}$ for the traditional roof and green roof respectively at $3 \mathrm{p}$.m. It can be noted that the green roof has significantly decreased the maximum inner surface temperature by $10.55^{\circ} \mathrm{C}$. the green roof reduces the heat flow inside the roof due to the presence of vegetation and the substrate, which acts as an insulating layer, thereby reducing the heat flux to the inside of the roof.

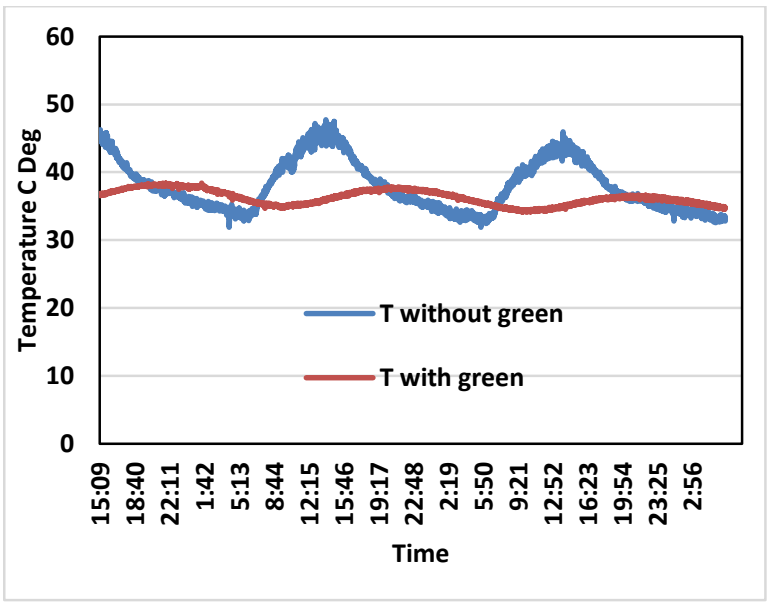

Figure 15. Roof internal surface temperature.
While Figure 16. Shows that temperature of the external roof surface. The results indicate that the maximum external surface temperature was 53.18 ${ }^{\circ} \mathrm{C}$ and $41.79{ }^{\circ} \mathrm{C}$ for traditional and green roofs (on vegetation layer), respectively. The maximum green roof surface temperature has decreased by $11.39{ }^{\circ} \mathrm{C}$. The reason for this decrease is that: the vegetation reduces solar radiation penetration, external temperature, and relative humidity as it passes through the foliage in addition to that the substrate contains moisture and acts as an insulation layer, so decreases the temperature that reaches the external surface of the green roof.

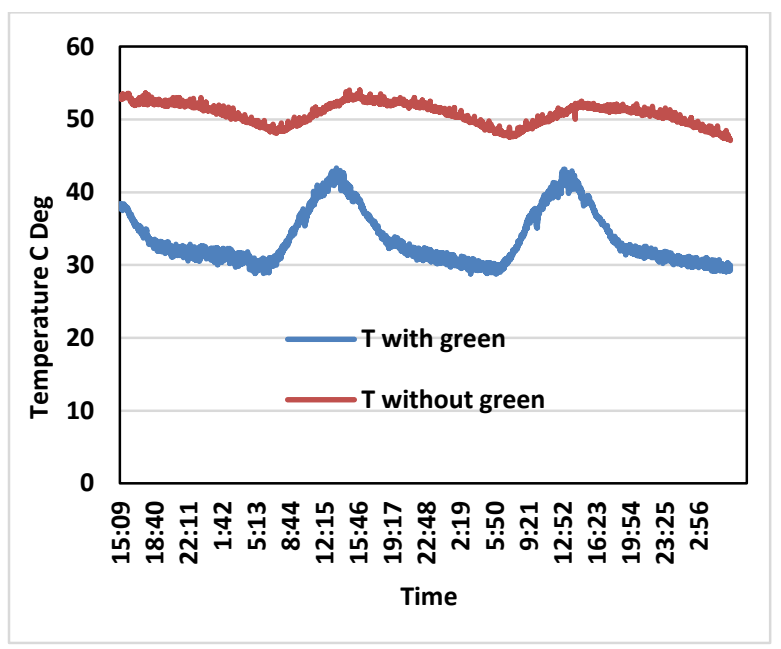

Figure 16. The temperature of the external surface of the roof.

\subsection{Saving in electricity cost}

The value of cooling load was calculated from equation (1), and the assumption of the building used is a residential building and cooling control operates a half-day as well as it was assumed that the effect of the green layer is neglected due to the difficulty of calculating the thermal resistance of this layer and also that the results obtained as a result of the existence of this layer. Also, the consumption category was chosen from the second category with average consumption (1501 - 300) kilowatt per hour at a price of 35 dinars, per unit [25]. To calculate the savings in the cost of electricity during the summer season, assuming that the summer season consists of four months. Fig. 17 shows saving in electricity cost.

Table 2. Saving in electricity for period 18-21 July 2019.

\begin{tabular}{lllll}
\hline $\begin{array}{l}\text { Date } \\
\text { (July 18-21) }\end{array}$ & $\begin{array}{l}\text { Cooling load } \\
(\mathbf{W})\end{array}$ & $\begin{array}{l}\text { saving in electricity cost } \\
\text { Dinar/ day }\end{array}$ & $\begin{array}{l}\text { saving in electricity cost } \\
\text { Dinar/ Month }\end{array}$ & $\begin{array}{l}\text { saving in electricity } \\
\text { cost Dinar/ summer session }\end{array}$ \\
\hline St. Roof & 8.47 & 3.55 & 106.7 & 426.88 \\
Gr. Roof & 8.04 & 3.37 & 101.3 & 405.2 \\
\hline
\end{tabular}

Table 3. Saving in electricity for period 5-8 of September 2019.

\begin{tabular}{lllll}
\hline $\begin{array}{l}\text { Date } \\
\text { (September 5-8) }\end{array}$ & $\begin{array}{l}\text { Cooling load } \\
\text { (W) }\end{array}$ & $\begin{array}{l}\text { saving in electricity cost } \\
\text { Dinar/ day }\end{array}$ & $\begin{array}{l}\text { saving in electricity cost } \\
\text { Dinar/ Month }\end{array}$ & $\begin{array}{l}\text { saving in electricity } \\
\text { cost Dinar/ summer session }\end{array}$ \\
\hline St. Roof & 8.45 & 3.55 & 106.45 & 425.8 \\
Gr. Roof & 6.16 & 2.59 & 77.6 & 310.46 \\
\hline
\end{tabular}




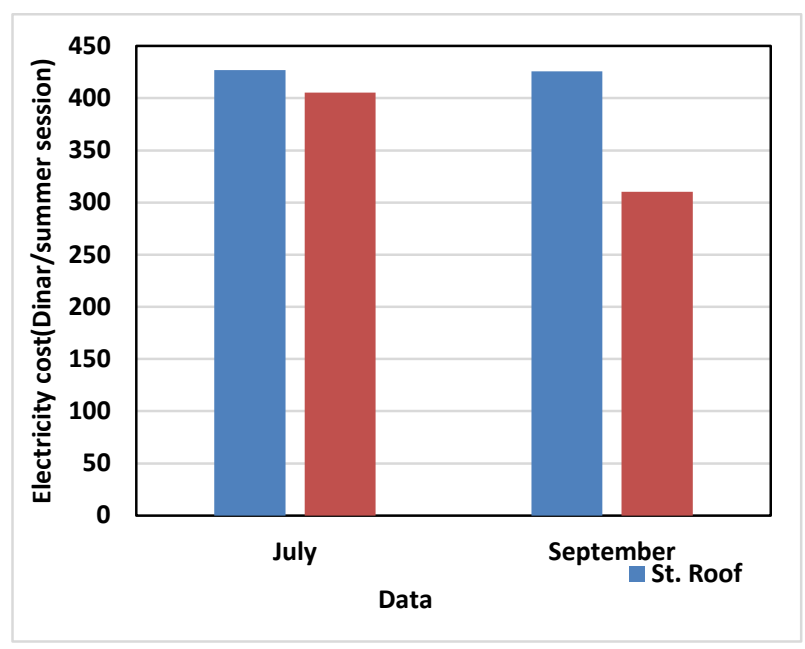

Figure 17. Saving in electricity cost for July and September 2019.

\section{Conclusion}

In this paper, experimental investigation is made to study the effect of the green roof to reduce the heat transfer to the interior of the building and compare it to the traditional roof. The results of this work are summarized as follows:

- Through the experimental results of July, we notice that the temperature of the zone decreased by $7.5^{\circ} \mathrm{C}$. While the maximum temperature of the traditional internal roof surface is $45.66^{\circ} \mathrm{C}$ and $37.41^{\circ} \mathrm{C}$ for the green roof. As for the month of September, the temperature of the zone decreased by $9.34^{\circ} \mathrm{C}$, The maximum temperature was $46.97{ }^{\circ} \mathrm{C}$ and $36.42^{\circ} \mathrm{C}$ for the traditional roof and green roof respectively at 15:00 pm. It can be seen that the green roof has significantly reduced the maximum internal surface temperature by $10.55^{\circ} \mathrm{C}$.

- The cost of reducing the cooling load and saving electricity was $26.8 \%$ for September and $5.06 \%$ for July.

- The performance of the green roof system depends largely on three factors, the geographical location of the building and the leaf area index, in addition to the depth of the growth substrate (soil). The higher the depth of the soil, the greater the rate of reduction in consumption due to the increase in the value of the insulation and the thermal mass.

- The reduction in load by using green roof was $27.1 \%$ for September and $5.08 \%$ for July.

\section{REFERENCES}

[1] The annual statistical report in Iraq, Electrical Energy production, center for information and control. 2018.

[2] E. Pledge, Green roofs: ecological design and construction, Schiffer Pub Limited2005.

[3] K.L. Getter, D.B. Rowe, B.M. Cregg, Solar radiation intensity influences extensive green roof plant communities, Urban Forestry \& Urban Greening 8(4) (2009) 269-281.

[4] R.A. Francis, J. Lorimer, Urban reconciliation ecology: the potential of living roofs and walls, Journal of environmental management 92(6) (2011) 1429-1437.

[5] E. Oberndorfer, J. Lundholm, B. Bass, R.R. Coffman, H. Doshi, N. Dunnett,
S. Gaffin, M. Köhler, K.K. Liu, B. Rowe, Green roofs as urban ecosystems: ecological structures, functions, and services, BioScience 57(10) (2007) 823833.

[6] O. Saadatian, K. Sopian, E. Salleh, C. Lim, S. Riffat, E. Saadatian, A. Toudeshki, M. Sulaiman, A review of energy aspects of green roofs, Renewable and Sustainable Energy Reviews 23 (2013) 155-168.

[7] C.-F. Chen, Performance evaluation and development strategies for green roofs in Taiwan: A review, Ecological engineering 52 (2013) 51-58.

[8] D. Townshend, A. Duggie, Study on green roof application in Hong Kong, Architectural services department (2007).

[9] K. Liu, J. Minor, Performance evaluation of an extensive green roof, Presentation at Green Rooftops for Sustainable Communities, Washington DC (2005) 1-11.

[10] H. Takebayashi, M. Moriyama, Surface heat budget on green roof and high reflection roof for mitigation of urban heat island, Building and environment 42(8) (2007) 2971-2979.

[11] S. Saiz, C. Kennedy, B. Bass, K. Pressnail, Comparative life cycle assessment of standard and green roofs, Environmental science \& technology 40(13) (2006) 4312-4316.

[12] S. Attia, A. Mahmoud, Green Roofs in Cairo: A Holistic Approach for Healthy Productive Cities, Proceedings of 7th Annual Greening Rooftops for Sustainable Communities (2009).

[13] I. Jaffal, S.-E. Ouldboukhitine, R. Belarbi, A comprehensive study of the impact of green roofs on building energy performance, Renewable energy 43 (2012) 157-164.

[14] S.S. Moody, D.J. Sailor, Development and application of a building energy performance metric for green roof systems, Energy and buildings 60 (2013) 262269.

[15] P. La Roche, U. Berardi, Comfort and energy savings with active green roofs, Energy and buildings 82 (2014) 492-504.

[16] C.Y. Jim, Air-conditioning energy consumption due to green roofs with different building thermal insulation, Applied Energy 128 (2014) 49-59.

[17] J. Coma, G. Pérez, C. Solé, A. Castell, L.F. Cabeza, Thermal assessment of extensive green roofs as passive tool for energy savings in buildings, Renewable Energy 85 (2016) 1106-1115.

[18] Y.M.M. Saleem, A.F. Abdulrasoul, A comparative study for the effect of green roofs in the local climate of Najaf city, The iraqi journal of architecture and planning 11(3) (2015) 197-213.

[19] L. Jiang, M. Tang, Thermal analysis of extensive green roofs combined with night ventilation for space cooling, Energy and Buildings 156 (2017) 238-249.

[20] A.B. Besir, E. Cuce, Green roofs and facades: A comprehensive review, Renewable and Sustainable Energy Reviews 82 (2018) 915-939.

[21] J. Coma, G. Pérez, C. Solé, A. Castell, L.F. Cabeza, Thermal assessment of extensive green roofs as passive tool for energy savings in buildings, Renewable Energy 85 (2016) 1106-1115.

[22] Ministry of construction and housing: republic of Iraq., Thermal insulation guide: Iraqi construction guide, (First edition, 2013).

[23] J.P. Holman, J.P. Holman, Heat transfer, McGraw-Hill Companies 1976.

[24] M.I. Hasan, H.O. Basher, A.O. Shdhan, Experimental investigation of phase change materials for insulation of residential buildings, Sustainable cities and society 36 (2018) 42-58.

[25] Annual statistical report for the overal electrical production in Iraq, Iraq (2017). 